\title{
The incorporation of women's empowerment principles (WEPs) as criteria for granting the national social responsibility seal for prison work (RESCUE)
}

\author{
A incorporação dos princípios de empoderamento das mullheres (WEPS) como critério para a \\ concessão do Selo Nacional de Responsabilidade Social pelo Trabalho Prisional (RESGATA) \\ La incorporación de los principios de empoderamiento de las mujeres (WEPs) como criterio para la \\ concesión del Sello Nacional de Responsabilidad Social por el Trabajo Penitenciario (RESGATA)
}

Received: 09/05/2021 | Reviewed: 09/11/2021 | Accept: 09/13/2021 | Published: 09/14/2021

\author{
Ana Maria D’Ávila Lopes \\ ORCID: https://orcid.org/0000-0001-7047-0997 \\ Universidade de Fortaleza, Brazil \\ E-mail: anadavilalopes@uniofor.br \\ Marynna Laís Quirino Pereira \\ ORCID: https://orcid.org/0000-ooo2-9648-2205 \\ Universidade Federal de Minas Gerais, Brazil \\ E-mail: marynnaqp@gmail.com \\ Lucas Vieira Barjud Marques \\ ORCID: https://orcid.org/0000-0002-7682-6306 \\ Universidade de Fortaleza, Brazil \\ E-mail: lucasbarjud@gmail.com
}

\begin{abstract}
Gender discrimination against women in the labor market remains a global scourge. This situation is even more aggravated in the case of women prisoners or ex-prisoners, who suffer not only from gender bias, but from their involvement with the criminal world. In this context, the present work aimed to propose the incorporation of the Women's Empowerment Principles (WEPs) proposed by the United Nations (UN), as a new criterion for the granting of the National Seal of Social Responsibility for Prison Work (RESCUE). The RESCUE, created in 2017 by the National Penitentiary Department (DEPEN), of the Brazilian State, has the purpose of recognizing the initiatives of public and private institutions that hire people deprived of their liberty or those released from the national prison system. For this purpose, bibliographic and documentary research was carried out on Brazilian doctrine and legislation, as well as on UN documents. It was concluded that there is a need and urgency for the Brazilian State to improve the mechanisms for the inclusion of women in the labor market, especially in the case of those prisoners or those who are discharged from the penitentiary system, being RESCUE an important initiative that can be significantly improved by including WEPs, as one of the criteria for its award.
\end{abstract}

Keywords: Women's rights; Empowerment; WEPS; RESCUE; Women in prison.

\section{Resumo}

A discriminação de gênero contra a mulher no mercado de trabalho continua sendo um flagelo mundial. Essa situação se agrava ainda mais no caso de mulheres presas ou egressas do sistema prisional, que sofrem não apenas o preconceito de gênero, mas o preconceito pelo seu envolvimento com o mundo do crime. Nesse contexto, o presente trabalho objetivou propor a incorporação dos Princípios de Empoderamento das Mulheres (WEPs) propostos pela Organização das Nações Unidas (ONU), como um novo critério para a concessão do Selo Nacional de Responsabilidade Social pelo Trabalho Prisional (RESGATA). O RESGATA, criado em 2017 pelo Departamento Penitenciário Nacional (DEPEN), do Estado brasileiro, possui o propósito de reconhecer as iniciativas das instituições públicas e privadas que contratam pessoas privadas de liberdade ou egressos do sistema prisional nacional. Com essa finalidade, foi realizada pesquisa bibliográfica e documental na doutrina e legislação brasileira, bem como em documentos da ONU. Concluiu-se pela necessidade e urgência do Estado brasileiro de aprimorar os mecanismos de inclusão das mulheres no mercado de trabalho, especialmente no caso daquelas presas ou egressas do sistema penitenciário, sendo o RESGATA uma importante iniciativa que pode ser significativamente aperfeiçoada ao serem incluídos os WEPs como um dos critérios para sua concessão.

Palavras-chave: Direitos das mulheres; Empoderamento; WEPS; RESGATA; Mulheres presas. 


\begin{abstract}
Resumen
La discriminación de género contra las mujeres en el mercado laboral sigue siendo un flagelo mundial. Esta situación se agrava aún más en el caso de las mujeres presas o ex-presas, que sufren prejuicios no sólo por su género, sino también por su envolvimiento con el mundo criminal. En este contexto, el presente trabajo tuvo como objetivo proponer la incorporación de los Principios de Empoderamiento de la Mujer (WEPs) propuestos por las Naciones Unidas (ONU), como un nuevo criterio para el otorgamiento del Sello Nacional de Responsabilidad Social del Trabajo Penitenciario (RESGATA). El RESGATA, creado en 2017 por el Departamento Nacional Penitenciario (DEPEN), del Estado brasileño, tiene el propósito de reconocer las iniciativas de las instituciones públicas y privadas que contratan personas privadas de libertad o egresadas del sistema penitenciario nacional. Para ello, se llevó a cabo una investigación bibliográfica y documental sobre la doctrina y la legislación brasileñas, así como sobre documentos de la ONU. Se concluyó que existe la necesidad y urgencia de que el Estado brasileño mejore los mecanismos de inclusión de las mujeres en el mercado laboral, especialmente en el caso de las que están presas o de las que son egresadas del sistema penitenciario, siendo el RESGATA una importante iniciativa que puede ser significativamente perfeccionada al incluirse los WEPs, como uno de los criterios para su concesión.
\end{abstract}

Palabras clave: Derechos de las mujeres; Empoderamiento; WEPS; RESGATA; Mujeres presas.

\title{
1. Introduction
}

In 2000, Kofi Annan, then Secretary-General of the United Nations (UN), launched the Global Compact (PG-UN), with the purpose of promoting companies to align their strategies and activities around ten principles structured in three areas: human rights, work and the environment (Annan, 2000). In 2004, the area of combating corruption was added. The PG-UN is today the largest corporate sustainability initiative in the world, encompassing more than 13,000 companies from 160 countries, aimed at achieving the Sustainable Development Goals (SDGs) (Kell \& Levin, 2012).

Thus, based on Objective 5 (Gender Equality), the PG-UN and UN Women approved, in 2010, the Women's Empowerment Principles (WEPs) so that business entities could incorporate gender equity values and practices as a way to empower women.

In this context, the present work aims to propose the incorporation of WEPs as a criterion for the granting of the National Seal of Social Responsibility for Prison Work (RESCUE).

RESCUE was created in 2017 by the National Penitentiary Department (DEPEN), of the Brazilian State, with the purpose of recognizing the initiatives of public and private institutions that hire people deprived of their liberty or egressed from the national prison system, in view of the difficulty of their insertion in the labor market.

The difficulty of insertion in the labor market of persons deprived of liberty or those who have left the prison system is even more serious in the case of women who, historically, have already suffered discrimination in all social fields (Cabral \& Silva, 2010). It is, therefore, crucial to recognize this intersectionality in order to implement measures that can contribute to the reversal of this situation of exclusion.

The work is divided into three parts. Thus, initially, the basic aspects of gender discrimination against women prisoners will be exposed to, then, address the context of the emergence of WEPs and their content. Finally, it will be proposed to incorporate the WEPs into the RESCUE, as a way to improve this program, given its potential to contribute to the empowerment of women prisoners or those discharged from the prison system, seeking to reverse the situation of discrimination in which they find themselves.

\section{Methodology}

The steps that were taken to reach the proposed objectives were achieved through a methodology that prioritized systematic literature review. In addition to the analysis of existing legal and doctrinal parameters on the subject, it was sought, through a propositional approach, mechanisms that would help to solve the problem analyzed. 
Regarding its objectives, the research was exploratory, explanatory, and descriptive. Exploratory because it intends to provide a broad and general view of the gender discrimination against women in prison or those who are discharged from the Brazilian prison system, with a view to clarifying existing concepts and their historical-temporal and spatial contextualization. It was also characterized as explanatory, since it consisted in the search for the identification of legal factors that can contribute to overcoming the problem. And, finally, it was also descriptive, as it aimed to categorize the problem investigated, identifying and individualizing it. With regard to the use of results, it was pure, as it sought to expand knowledge about the topic and its interfaces, finally indicating an adequate solution to the problem analyzed.

\section{Results and Discussion}

\subsection{Discrimination against women in prison}

At the beginning of a new century, much remains to be done in terms of achieving equality between men and women. Prejudice and gender discrimination continue to be present in contemporary society, which persists in repeating the mistakes of the past by imposing certain standards of behavior on women conceived as morally or socially good, discriminating anyone who decide not to follow those rules (Lopes \& Andrade, 2017).

This panorama can be clearly seen in the case of women prisoners and ex-prisoners, because they suffer even greater discrimination in relation to men in the same situation, since society censures women more than men who are involved in some event criminal, insofar as it contradicts the patriarchal view of women as mothers, wives, or daughters. A woman in prison is a woman who is not fulfilling her role as caregiver for the family and on whom the stigma of evil will be built. Who can trust her again? Frinhani and Souza (2005) claim that there is a social estrangement in relation to the involvement of women in the world of crime, causing double discrimination. For Haft (1974-1975): "As a group, women in prison suffer the mutually reinforcing problems of both women and prisoners", making it difficult for them to re-socialize. Minzon et al (2010) emphasize that, "Therefore, these women face a stigmatization process, because they committed crimes and run away from the rules imposed by society. Furthermore, they are always seen as prisoners and this stigma prevents the recognition of other characteristics and abilities that they can also have, reducing the chances of restructuring their lives after serving the prison sentence, that could hinder their reintegration in society, facilitating to commit the same crimes again".

This is a situation that must be urgently reversed, and it is the State's obligation to implement public policies aimed at combating these prejudiced social constructions to guarantee the effective exercise of the fundamental rights of women prisoners or those who are discharged from the prison system.

This obligation of the Brazilian State is provided for in item IV of art. 3, of the Federal Constitution of 1988 (CF / 88), which expressly establishes as one of its objectives "to promote the good of all without prejudice of origin, race, sex, color, age or any other forms of discrimination" (Brasil, 1988).

The equality of all people, as a fundamental principle of the Brazilian State, is reinforced in the caput of art. 5 of CF / 88, in which it is established that "all are equal before the law [...]" (Brasil, 1988), and this equality should be interpreted not from its strict sense derived from liberalism, which only considers equality in the formal sense (in the legal text), but as a material equality (equality in the text and in its application), imposing the need to treat equals as equal and unequal as unequal.

This requirement stems from the fact that, although as human beings we share the same essence, historically prejudiced values against certain human groups have been settled, whether due to their color, their sex, their religion, or other characteristics, triggering societies hierarchical, in which some are in positions of clear disadvantage, as in the case of women. That is why the State is required to apply the rules differently in specific cases and, even, to provide for special rules aimed at matching those who are at a disadvantage (Fraser, 2008). 
Based on this understanding, item I of art. 5, also from CF / 88 (Brasil, 1988), provides for equality between men and women, however allowing some exceptions such as, for example, the rules about retirement (item "a" of item III of paragraph 1 of art. 40 and paragraph 7 of art. 201) who demand less years from women to retire - either by age or length of contribution in view of the double working hours faced by them who, in addition to working outside the home, have to take care of all the household chores.

This is undoubtedly a formally unequal legal treatment, but not materially. Although in some countries most of the unjust differences between men and women are being overcome, it is still mostly present in Brazilian society, including in the penitentiary centers. According to Cortina (2015): “The treatment given to women in Brazilian prisons is a chaotic scene of multiple violations of human rights and a space for the depth of inequalities. A prison experience for women, by different aspects, represents a plus in relation to punishment for men”. Along these lines, Santos et. al. (2020, p. 15) observe that Brazilian prisons were designed to receive a male population, but not a female one, which causes precarious treatment and is unable to meet the needs of women,

The degrading conditions of women's prisons lead many women to commit suicide or self-injury as highlighted by Carvalho et. al. (2021, p. 1), "self-injury and suicide attempt before incarceration was reported by $11.3 \%$ and $35.5 \%$ of the sample, respectively. During imprisonment, a prevalence of $29 \%$ and 18.8 for selfinjury and suicide attempt, respectively, was observe".

With respect to $\mathrm{CF} / 88$, the State must, therefore, implement policies that help to insert people imprisoned or discharged from the prison system into the labor market, placing a greater emphasis on women, who face double discrimination, doubling their social vulnerability (Santoro \& Pereira, 2018).

\subsection{The principles of women's empowerment (WEPs)}

The Women's Empowerment Principles (WEPs) were created in 2010 by an initiative of the Global Compact (PGUN) and the United Nations Entity for Gender Equality and Women's Empowerment (UN Women), based on Goal 5 (Gender Equality) of the Sustainable Development Goals (SDGs), to promote the incorporation of values and practices of gender equity and the empowerment of women in business (UN Women, 2016).

WEPs were formulated based on the normative basis of the International Labor Organization (ILO), those related to the scope of work, being released by the PG-UN so that companies can implement them. Compliance is measured using indicators formulated by UN Women.

It assumes, that it is necessary to empower women to participate actively in all sectors of the economy, in order to build strong economies and more just and stable societies, improving the quality of life for the whole of society.

In this sense, WEPs are tools to direct companies in their initiatives for the empowerment of women, contributing to the creation or adaptation of existing policies and practices. There are seven principles (WEPs, 2020):

a) High-level corporate leadership: part of the premise that high-level leadership is one that promotes gender equality, that is, there is no change in corporate culture if its own leaders are not committed to fighting discrimination against gender and demonstrate commitment to its achievement;

b) Treat all men and women fairly at work, without discrimination: it refers to the fair and equal treatment that everyone should receive in the work environment, which means guaranteeing equal opportunities for men and women by promoting inclusion and not discrimination;

c) Health, safety and well-being for all: refers to the need for companies to recognize that these three areas are directly influenced by the gender of the worker, in order to plan actions that avoid reinforcing gender stereotypes; 
d) Education and training for gender equality: education is a strategic resource for removing obstacles to equality, since it is through knowledge that women can fully develop their capacities and have the same opportunities as men;

e) Business development, supply chains and marketing practices: companies need not only to change their internal organizational culture, but they must also realize that they can influence the change in behavior of other corporations through their example of combating gender discrimination;

f) Community initiatives and advocacy: companies must promote social responsibility programs aimed at women in the community where they are located, contributing to their empowerment and building a more just social environment;

g) Measurement and reporting: business companies must set quantitative targets and always monitor them. The progress achieved must be published in reports and problems that persist must be reported. Thus, with other stakeholders, companies can implement solutions.

From this synthesis of the content of the WEPs, it is possible to observe the wide list of areas in which business entities can act in order to contribute to the reversal of the situation of discrimination in which women find themselves, contributing to their empowerment and full insertion in society as protagonists of their own history.

\subsection{The incorporation of WEPS in RESCUE}

RESCUE was created by the National Penitentiary Department (DEPEN), of the Brazilian State, through Ordinance No. 630, of November 3, 2017 (Brasil, 2017), with the purpose of recognizing the initiatives of public and private institutions that hire at least $3 \%$ of people deprived of liberty or released from the national prison system.

In the first cycle of the RESGATA (2017/2018), 112 institutions in Brazil were awarded the seal, also recognizing the role of the Secretaries of Prison Administration, from the different states of the federation, for their search to establish new partnerships with the private sector and, in this way, expand the hiring of prisoners or former prisoners.

RESCUE was created based on the provisions of art. 126 of Law No. 7,210, of July 11, 1984 (Brasil, 1984), Law of Penal Execution (LEP), which recognizes one day less penalty for every 3 days of labor activity of those sentenced to deprivation of liberty in an open or semi-open regime, being known as the institute of redemption. RESCUE, therefore, assumes that work is one of the main pillars of resocialization, contributing "to personal and collective development. Work brings back dignity, rescues self-esteem and provides conditions for personal and family livelihood" (Brasil, 2021). Also, Andrade and Ramos (2020), in research about work and prison carried out in a penitentiary progression center of the city of Belém do Pará, showed that prisoners and ex-prisoners inserted in the labor market have less chance of relapse into crime.

In the most recent cycle of the Rescue (2019/2020), 372 entities received, on July 8, 2020, the seal for hiring almost 17 thousand prisoners or ex-prisoners, showing an important increase in the number of institutions participating in the program (232\%) (Brasil, 2020). These entities, public or private, go through a selection process and must offer a healthy working environment compatible with the physical conditions of the worker, as well as demonstrating that they develop activities to change the socio-economic reality of them, offering work opportunities that help to overcome prejudices against people arrested or discharged from the prison system. Costa and Bratkowski (2007) affirm that the hiring of prisoners "it is seen, in a certain way, as a taboo by Brazilian society, it can be verified from experiences that show only production works in prisons, generally in low qualification services." (Brasil, 2017).

For the contracting entities, public or private, the advantages pointed out are the lower cost compared to an ordinary worker, because can pay $3 / 4$ of the minimum wage, ease in replacement and replacement workers, as well as the absence of strikes and stoppages.

These advantages of RESCUE for the State, for society, for people imprisoned or discharged from the penitentiary system and for contracting entities can be enhanced, especially in the case of women, if WEPS were inserted as a criterion for 
the selection, in whatever is appropriate, because it would be a measure that would contribute to reduce the discrimination that exists against them, considering that in the prison universe gender stereotypes are repeated. Cortina (2015) explains that "The administration methodology in feminine prisons reproduce the perpetual gender discrimination. An example can be founded in São Paulo feminine penitentiary, where the work offered to women, in most of the times, was related to activities typical of the female sex (knitting, embroidering, sewing, taking care of appearance, making confectionery)'. Similarly, in Portugal, I observe that the women prisoners are trained exclusively in domestic jobs, including cooking, preparation of manual rugs, sewing and washing of clothes from male prison [...]. A discrimination against women in the labor market is reproduced in jail and, undoubtedly, will continue in free life".

To include WEPs as a selection criterion for the concession of RESCUE, the Brazilian State would be applying the constitutional rules that not only prohibit any form of discrimination but establish the obligation to interpret equality in its material sense, to require the elaboration of laws and the implementation of public policies against prejudiced values that still prevail in our society.

According to Bocorny (2003, p. 41), valuing the human work implies to admit work (and the worker) as the main agent of transformation of the economy and his/her social insertion. This understanding will not be seen as a simple mechanism to produce wealth. Valuing the human work is equivalent to reconfirming the dignity of every human being. Cecato (2008, p. 178) explains that, when work is carried out under dignified conditions, it becomes a material, moral and emotional provision of the worker, reducing his/her vulnerability during violence or exploration, especially of the imprisoned worker.

\section{Conclusion}

The PG-UN's concern with gender equality at work was clearly manifested by participating in the project that formulated the Women's Empowerment Principles (WEPs), in 2010, created jointly with UN Women, in order to provide companies, the necessary guidelines for them to act promoting equality between men and women, eliminating discrimination in the workplace, in the market and in society in general.

This relevant initiative can be incorporated as one of the criteria for the granting of the RESGATA seal, created by DEPEN in 2017, to give visibility to entities, public or private, that hire prisoners or former prisoners.

Considering the double discrimination that women in prison or those who are discharged from the prison system suffer in Brazilian patriarchal society, because they are women and because they are imprisoned, WEPs can be a valuable tool to combat discrimination against these women in the workplace, contributing not only for its re-socialization, but for the construction of a less prejudiced and more just society.

However, it is important to note that only the reform of the rules that regulate the RESGATA will be enough for the proposal to reach its goals. Mechanisms for monitoring the application of this new criterion should be implemented, as a way to guarantee its effectiveness or, even, to make any adjustments. In this sense, further research should be carried out in order to identify whether or not the proposal is contributing to change the panorama of discrimination experienced by women in prison or those who are discharged from the Brazilian prison system.

\section{Acknowledgments}

The research was financed by DPDI/UNIFOR 


\section{References}

Andrade, A. \& Ramos, E. (2020). Work and prison: the profile of the prisoners at Belém's Penitentiary Progression Center, Pará State, Brazil. Research, Society and Development, 9 (9), 1-17. https://rsdjournal.org/index.php/rsd/article/view/7251/6538

Annan, K. (2000). Kofi Annan's address to World Economic Forum in Davos, 01 feb. 1999. https://www.un.org/sg/en/content/sg/speeches/1999-02-01/kofiannans-address-world-economic-forum-davos

Bocorny, L. (2003). A valorização do trabalho humano no Estado Democrático de Direito. SAFE.

Brasil. (2021). Ministério de Justiça e Segurança Pública. Selo Resgata. 2021. https://www.justica.gov.br/mulheres-livres/selo-resgata

Brasil. (2017). Ministério de Justiça e Segurança Pública. Portaria $n^{\circ}$ 630, de 3 de novembro de 2017. https://www.justica.gov.br/news/collective-nitf-content1557163227.72

Brasil. (2020). Agência Brasil. Ministério certifica instituições por contratar quase 17 mil presos. No total, 432 instituições receberam a certificação do governo. 2020. https://www.justica.gov.br/mulheres-livres/selo-resgata

Brasil. (1988). Constituição da República Federativa do Brasil, 5 de outubro de 1988. http://www.planalto.gov.br/ccivil_03/Constituicao/Constituiçao.htm

Brasil. (1984). Lei $n^{o} 7.210$, de 11 de julho de 1984. Institui a Lei de Execução Penal. http://www.planalto.gov.br/ccivil_03/leis/17210.htm

Cabral, L. \& Silva, J. (2010). O trabalho penitenciário e a ressocialização do preso no Brasil. Revista do CAAP, (1), 157-184. https://revistadocaap.direito.ufmg.br/index.php/revista/article/view/277

Carvalho, E., Mateus, K., Lima, K., Silva, J. \& Uchida, R. (2021). Self-injury and suicide attempt in incarcerated women: prevalence and risk factors. Research, Society and Development, 10 (7), 1-11. https://rsdjournal.org/index.php/rsd/article/view/15788/14576

Cecato, M. (2008). Direito laborais e desenvolvimento: interconexões. Boletim de Ciências Econômicas. 51, 173-191. https://digitalisdsp.uc.pt/bitstream/10316.2/24750/1/BoletimLI_Artigo6.pdf?ln=pt-pt

Cortina, M. (2005). Mulheres e tráfico de drogas: aprisionamento e criminologia feminista. Estudos Feministas, 3 (3), 761-778. https://www.scielo.br/pdf/ref/v23n3/0104-026X-ref-23-03-00761.pdf

Costa, S. \& Bratkowski, P. (2007). Paradoxos do trabalho prisional na era do capitalismo flexível: o caso do DETRAN-RS. Revista de Administração Contemporânea, 11 (3), 127-147. https://rac.anpad.org.br/index.php/rac/article/view/541

Fraser, N. (2008). La justicia social en la era de la política de la identidad: redistribución, reconocimiento y participación. Revista de Trabajo. 4 (6), 83-89. https://trabajo.gob.ar/downloads/igualdad/08ago-dic_fraser.pdf

Frinhani, F. \& Souza, L. (2005). Mulheres encarceradas e espaço prisional: uma análise de representações sociais. Psicologia: teoria e prática. 7 (1), 61-79. http://pepsic.bvsalud.org/scielo.php?script=sci_arttext\&pid=S1516-36872005000100006

Haft, M. (1974-1975). Women in prision: discriminatory practices and some legal solutions. Clearinghouse.1 8 (1) https://heinonline.org/HOL/LandingPage?handle=hein.journals/clear8\&div=4\&id=\&page=

Kell, G. \& Levin, D. (2012). The evolution of Global Compact Network: an historic experiment in learning and action. The Academy of Management Annual Conference - Building Effective Network, Denver.

Lopes, A. \& Andrade, D. (2017). O direito fundamental à maternidade da mulher gestante soropositiva. Direito $e$ Liberdade. 19 (1), 13-33. http://www.mpsp.mp.br/portal/page/portal/documentacao_e_divulgacao/doc_biblioteca/bibli_servicos_produtos/bibli_informativo/bibli_inf_2006/Rev-Dir-eLiberd_v.19_n.01.01.pdf

Minzon, C et al. (2010). Sistema prisional: conhecendo as vivências da mulher inserida neste contexto. Akrópolis. 18 (1), 71-81. https://revistas.unipar.br/index.php/akropolis/article/view/3118/2212

Santoro, A. \& Pereira, A. (2018). Gênero e prisão: o encarceramento de mulheres no sistema penitenciário brasileiro pelo crime de tráfico de drogas. Meritum. 13 (1), 87-112. https://edisciplinas.usp.br/pluginfile.php/5768805/mod_resource/content/1/Antonio\%20Eduardo\%20Ramires\%20Santoro \%20e\%20Ana\% 20 Carolina $\% 20$ Antunes $\% 20$ Pereira $\% 20-\% 20$ Genero $\% 20 \mathrm{e} \% 20$ prisao $\% 20-\% 20 \mathrm{o} \% 20$ encarceramento $\% 20 \mathrm{de} \% 20 \mathrm{mulheres} \% 20$ no $\% 20$ si stema $\% 20$ penitencia rio $\% 20$ brasileiro $\% 20$ pelo $\% 20$ crime $\% 20 \mathrm{de} \% 20$ trafico $\% 20 \mathrm{de} \% 20 \mathrm{drogas}$.pdf

Santos, F., Gouvêa, R., Bezerrar Neto, F., Caiana, C. \& Victor, G. (2020). The conditions of the Brazilian prison system in contrast to the fundamental rights of incarcerated women. Research, Society and Development, 9 (7), 1-20. https://rsdjournal.org/index.php/rsd/article/view/4602/4139

ONU Mulheres (2016). Princípios de Empoderamento das Mulheres. http://www.onumulheres.org.br/wp-content/uploads/2016/04/cartilha_ONU_M ulheres_Nov2017_digital.pdf

WEPs (2020). About. Women's Empowerment Principles https://www.weps.org/about 